\section{A WORD ON TRACHEOTOMY.}

By C. F. MAUNDER, EsQ., F.R.C.S., ASSISTANT-SURGEON, LONDON HOSPITAL.

IN the performance of tracheotomy, the introduction of a canula under circumstances requiring its use is usually deemed to be the most difficult step in the operation-a difficulty due to the constant and rapid elevation and depression of the trachea during respiration and deglutition. This difficulty is especially felt in children, in whom the windpipe is small and yielding. To overcome this obstacle I would beg to suggest a procedure which will facilitate the completion of the operation.

The trachea having been incised longitudinally, the operator should insert the point of a double hook through the incision into the windpipe, and hold the latter elevated and fixed; he should then slip up the clasp and allow the halves of the hook to separate by their own elasticity, and so to widen the slit in the trachea; this done, the canula may be passed into the tube with comparative ease, and the hook withdrawn.

Should any difficulty be experienced in the attempt to open the trachea after division of the softer tissues, the organ may be fixed in the adult by holding the cricoid cartilage firmly with the finger and thumb, or by a sharp hook inserted into the latter cartilage through the upper angle of the wound. In the child the sharp hook should be used.

Although a double canula be used and the inner one be removed at intervals, cleaned, and replaced, still mucus becomes inspissated, and, adhering to the extremity of the larger tube, offers a serious obstacle to respiration. This inconvenience may be remedied, while the inner tube is being cleaned, by the careful introduction of a small elastic catheter-well warmed, so as to soften it, and oiled - quite through the larger tube just into the trachea. By this means a passage is cleared and the obstruction is removed.

Again, although a double canula be used, mucus collects at the further extremity, and cannot always be dislodged either by cleaning the inner tube or by a catheter or feather; both must therefore be removed and cleaned, or be replaced by others. This necessity occurred to me in a case recently under my care; and in order to obviate the difficulty anticipated on re-introduction of the cleaned tubes, I first removed the inner canula, and then passed a small elastic catheter, well softened in hot water, through the outer tube into the trachea, and, maintaining it there, withdrew the tube over the catheter, and, as soon as it was cleaned, passed it back again along the catheter, still in the trachea, till the former occupied its original position; the eatheter was then removed from the trachea.

The catheter served both as a tube by which respiration could be sustained, and also as a guide for the re-introduction of the canula, after the manner of Wakley's catheters.

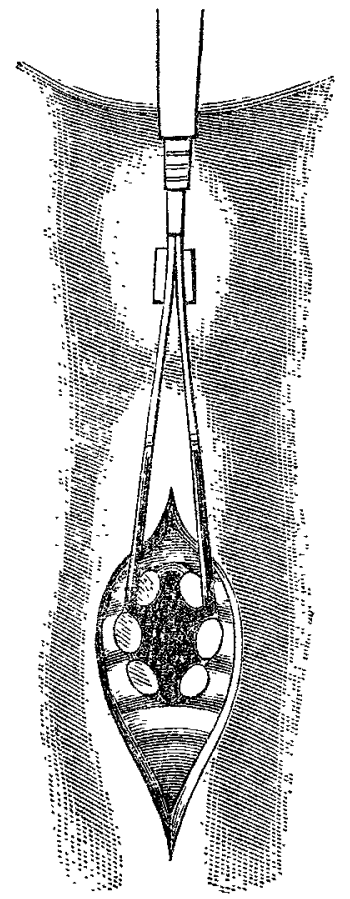

The figure shows the cut ends of three rings of the trachea, with their edges separated by the double hook sufficiently to admit of the ready introduction of a canula. The handle of the hook rests upon the patient's chin. Should the retention of a canula in the windpipe be deemed injurious, the slit may be kept permanently open by reversing the position of the double hook.

New Broad-street, Mareh, 1861.

\section{a a titrut}

OF THE PRACTICE OF

\section{MEDICINE AND SURGERY IN THE}

\section{HOSPITALS OF LONDON.}

Nulla est alia pro certo noscendi via, nisi quam plurimas et morborum ef dissectionum historias, tam aliorum proprias, collectas habere et inter se comparare.-MorGagn. De Sed. et Caus. Morb., lib. 14. Procnium.

\section{KING'S COLLEGE HOSPITAL.}

MELANOTIC TUMOUR OF THE LEFT ARM, GROWING FROM THE CICATRIX OF A MOLE ERADICATED BY CAUSTICS.

(Under the care of Mr. Fergusson.)

SInce the last report of cases of melanosis in the "Mirror," nearly four years ago, we have met with comparatively few examples of the disease. During the last few months, how. ever, two instances have presented themselves, wherein it was developed in the form of tumours; these we now publish, and add the sequel of a third case which appeared in a previous "Mirror."

The most frequent seat of melanosis is the eye or its appena dages; next in frequency come the skin and subcutaneous areolar structures. Moles, when irritated by some cause, often give rise to tumours of this kind; and these may assume either the benign or malignant form of the disease. Although in the great majority of instances melanosis is associated with some one of the varieties of cancer, it must be understood that the melanotic pigment per se does not constitute malignancy. Into this question we entered on a former occasion (THE LANCET, vol. i. 1856, p. 657). Dr. Walshe has, besides, clearly proved the incorrectness of the opinion of some pathologiststhat accumulations, whether fluid or solid, having a black colour, are not actually cancers. (See his valuable monograph on Cancer, p. 184.)

In each of the following cases the black deposit was associated with medullary cancer; therefore they form illustrations of "black cancer" properly so called-a term which should be restricted to melanosis when it produces a deposit in either the scirrhous or encephaloid carcinoma.

The seat of the disease in the first case was the cicatrix of a mole which had been destroyed by caustics. It is very probable that some granules of pigment remained to form a nidus for the propagation of the disease, now associated with cancer. The tumour commenced to form three years ago, as soon as cicatrization was complete; it was not larger than a walnut when removed, but was evincing a disposition to augment rapidly. Its true character was quite apparent on examining a section of it afterwards. For the notes of the case we are indebted to Mr. Charles S. Matthews, house-surgeon to the hospital.

J. B-, aged thirty-nine, single, a cook, and a member of a healthy family, admitted into No. 3 ward, January $30 t h$, 1861 , with a small melanotic tumour of the left upper arm. The history is, that a small mole had existed on the arm as long as she can remember. Some three years ago she observed that it had become raised a little above the general surface, and had assumed a warty appearance. To rid herself of it, she had caustics applied, producing a small ulcer, on the site of the mole. This soon healed, and then the tumour first began to grow in the cicatrix. It has cansed her a good deal of pain, and has been gradually increasing in size up to the time of her admission, when a tumour was found on the inner and back part of the arm, three or four inches above the con. 